\title{
Settlement of mussels Mytilus galloprovincialis on an exposed rocky shore in Ría de Vigo, NW Spain
}

\author{
Jorge Cáceres-Martínez, José Antonio F. Robledo, Antonio Figueras
}

Instituto de Investigaciones Marinas CSIC, Vigo, Eduardo Cabello, 6, E-36208 Vigo, Spain

\begin{abstract}
The mussel farming industry of the Galician region (NW Spain) requires that 60 to $70 \%$ of its seed supply is taken from rocky shore areas. However there are almost no quantitative data for a recruitment and settlement pattern. In the Ría de Vigo a continuous settlement throughout the year with a major settlement season from May to September was found, reflecting the presence of spawning mussels throughout the year and the occurrence of a major spawning period during the spring. The observed settlement pattern indicates the direct settlement of larvae from the plankton onto the adult beds and an immigration of mussels previously settled on other substrates. This pattern could be a response to the ecological and environmental conditions that occurred on the Galician rocky shores, but could also be a differential characteristic between Mytilus edulis and M. galloprovincialis
\end{abstract}

The blue mussel Mytilus galloprovincialis is the most important species in marine aquaculture in Spain, especially in Galicia (NW Spain) where production has

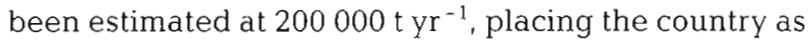
the biggest producer in the world (Figueras 1989, Pérez Camacho et al. 1991). The culture is carried out in areas protected from the ocean called Rías, with Ría de Vigo being one of the most important. The culture method uses floating rafts where ropes are hung with mussel seed for growth. Between 60 to $70 \%$ of seed come from natural beds on the oceanic side of the Rías and from the islands. Another source of seed is rope collectors placed on the rafts (Mariño et al. 1982, Figueras 1989, Pérez Camacho et al. 1991). The permanent availability of seed has been one of the main factors in the success of mussel culture in the region. However there are few studies on this subject.

Andreu (1958, 1965, 1968) described 2 settlement periods on the rocky shore, the most important from April to June with a second in autumn. Andreu (1976) detected the settlement of mussels of 0.5 to $1.0 \mathrm{~mm}$ on rope collectors but without giving quantitative data. This author suggested a different pattern of settlement to the primary stage settlement on filamentous substrates and a secondary stage settlement on adult mussel beds as described by Bayne (1964), Seed (1969, 1976), Dare (1976), Dare et al. (1983) and King et al (1989).

The aim of the present study was to determine the time and duration of the mussel settlement season and the settlement pattern.

Materials and methods. The study was carried out on the exposed rocky shore located in Cabo Home on the aceanic side of the Ría de Vigo $\left(42^{\circ} 15^{\prime} \mathrm{N}, 8^{\circ} 52^{\prime} \mathrm{W}\right)$. This area is well known as a source of seed for culture.

Twelve seed collectors made with nylon ropes (of the same kind as those used by local mussel farmers) of $35 \mathrm{~cm}$ length and $2 \mathrm{~cm}$ diameter $\left(225 \mathrm{~cm}^{2}\right)$ were placed in 2 stainless steel structures and attached on the lower shore, just above the Low Water Spring Tide level. Approximately each month between March 1991 and February 1992, 1 rope was replaced and, simultaneously, standard areas of $225 \mathrm{~cm}^{2}$, equivalent to the rope collector surface, were scraped directly on the adult beds.

Each collector was taken to the laboratory and the extraction of spat was done as follows: the rope was immersed in a $10 \%$ solution of commercial sodium hypochlorite $(\mathrm{NaClO})$ for $5 \mathrm{~min}$, and was rinsed with running water directly onto a series of 0.09 to $4.0 \mathrm{~mm}$ sieves. The fractions were dried in an oven at $80^{\circ} \mathrm{C}$ for $24 \mathrm{~h}$. The mussels were separated with a brush for their analysis using a stereoscopic microscope. All mussels in a fraction were counted except in June when it was necessary to make a random subsample of $20 \%$ of the total sample due to the high number of mussels present 


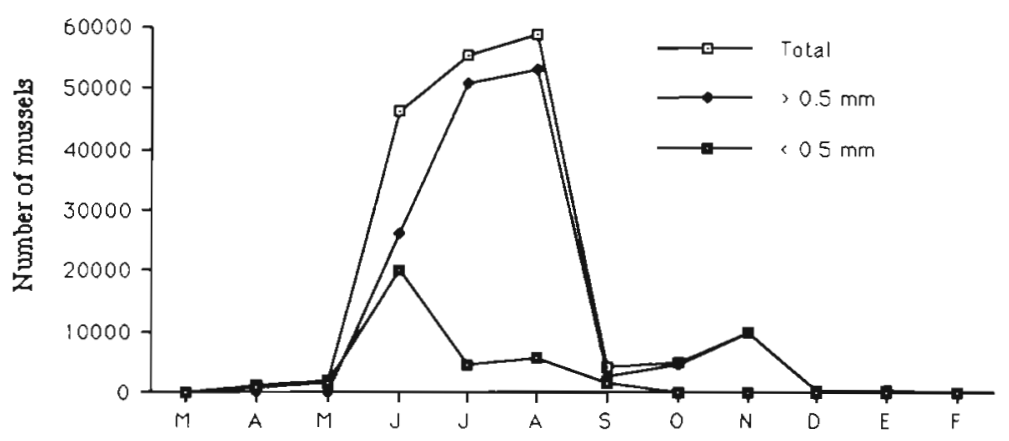

Fig. 1. Mytilus galloprovincialis. Monthly catches of primary $(<0.5 \mathrm{~mm})$ and secondary $(>0.5 \mathrm{~mm})$ stage mussel spat on rope collectors in Cabo Home, Ría de Vigo, during 1991-1992

in the 0.09 and $0.2 \mathrm{~mm}$ fractions. The mussels obtained in the sieves under $3 \mathrm{~mm}$ diameter were measured with a micrometer. Large mussels were measured with a caliper. Primary spat were separated considering mussels with shell lengths from 0.250 to $0.470 \mathrm{~mm}$ in accordance with the minimum and maximum values recorded for mature pediveliger larvae of Mytilus edulis (Rees 1954, Bayne 1965, Widdows 1991). This group was considered as $<0.500 \mathrm{~mm}$. The samples that came from the scraping of rocky areas were handled in the same way as those from the rope collectors.

Results. The total number of mussels obtained from the rope collectors throughout the study, and the contribution of the primary settlers $(<0.500 \mathrm{~mm})$ and secondary settlers $(>0.500 \mathrm{~mm})$ are shown in Fig. 1. The settlement peaked from May to September and remained low throughout other months but with a slight increase in November. The contribution of the primary spat $(<0.500 \mathrm{~mm})$ was mainly in June, at the start of the settlement season. During July and August the newly settled population was composed mainly of mussels belonging to length classes $>0.500 \mathrm{~mm}$, i. e. secondary spat.

The distributions of the frequencies of the length classes for the mussels obtained from the rope collectors and for the adult beds are shown in Fig. 2A, B. On the rope collectors (Fig. 2A) the primary stage (length classes $<0.500 \mathrm{~mm}$ ) occurred throughout the study period. An important increase appeared in May, though with low numbers of mussels. The maximum number of mussels in this length class was reached in June. A new increment occurred in September with low numbers of mussels. In June the secondary stage (length classes $>0.500 \mathrm{~mm}$ ) became more frequent as the total number of mussels increased. From this month there was a progressive occurrence of the longer length classes to a maximum in August. In November a slight increase of the secondary stage was again detected.

In the samples obtained from the adult bed (Fig. 2B) the primary spat (length classes $<0.500 \mathrm{~mm}$ ) also appeared throughout the study period. A clear increase was detected in May and September showing a similar fluctuation with the distribution obtained from the rope collector. The frequency changes in the length classes $>2.86 \mathrm{~mm}$ were minor.

Discussion. The presence of primary spat throughout the year and their abundance in May and June, reflects the presence of spawning mussels throughout the year and the occurrence of a major spawning period during the spring (Andreu 1958, 1965, 1968, Aguirre 1979, Figueras 1989). The increase of the length classes $<0.500 \mathrm{~mm}$ observed in September suggests a slight increase of spawning during the early autumn, however the number of these mussels was low. The increase in the number of mussels detected in November was major, but the contribution of primary settlers was reduced $(1 \%)$. It is thus difficult to confirm the occurrence of a second spawning season (Andreu 1958, 1965, 1968, Aguirre 1979, Figueras 1989). The results obtained suggest the occurrence of only 1 major spawning season with a recruitment period from May to September. This is in accordance with Pérez \& Roman (1979) who described 1 spawning and settlement season from March to August in the Ría de Arosa, based on data of mussel settlement on rope collectors. These authors assumed that spawning during the autumn, if it occurred, was scarce or that maybe the lower temperatures produced a great mortality of larvae. In the present study the presence of primary settlers $(<0.500 \mathrm{~mm})$ throughout the year, including the slight increase observed in September and November, suggests a survival of mussel larvae in the cooler season $\left(10\right.$ to $\left.12^{\circ} \mathrm{C}\right)$. A stereological study is being conducted to determine the incidence of the spawning in the populations throughout the year.

In June the number of primary settlers $(<0.500 \mathrm{~mm})$ and secondary settlers $(>0.500 \mathrm{~mm})$ were 20000 and 25000 respectively on rope collectors. A month later, the number of primary settlers $(<0.500 \mathrm{~mm})$ was 4000 while the number of secondary settlers $(>0.500 \mathrm{~mm})$ was 50000 (Fig. 1). This could be explained by the immigration of secondary settlers $(>0.500 \mathrm{~mm})$ to the rope collector and by the fast growth of primary settlers occurring on the rope collector during the warmer season. The capacity of the recently settled mussels to attach and detach several times has been previously described (Bayne 1964, 1965. Seed 1969, Tan 1975, Widdows 1991). The growth rate of recently settled Mytilus edulis is about $25 \mu \mathrm{m} \mathrm{d}^{-1}$ at 15 to $16^{\circ} \mathrm{C}$ (Bayne 1964). In this study the modal length in August was $2.860 \mathrm{~mm}$ when the mean temperature was $19.5^{\circ} \mathrm{C}$. With this figure the growth of primary settlers during the sampling period ( $30 \mathrm{~d}$ ) on the rope collector, taking 

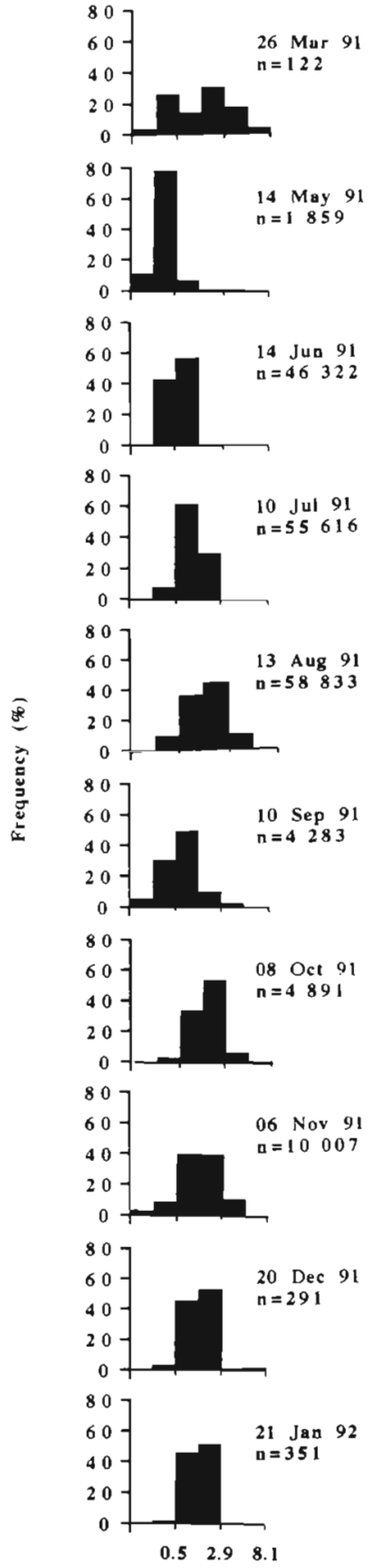

A

Shell length (mm)

B

Fig. 2. Mytilus galloprovincialis. Frequencies of 6 length classes $(0.250-0.350,0.351-0.470,0.471-1.500,1.501-2.900$, 2.901-5.599 and $5.600-8.100 \mathrm{~mm}$ ) of mussel spat settled each sampling period on (A) rope collectors and (B) adult beds in Cabo Home, Ría de Vigo

into account the modal value of the smallest length class in July $(0.320 \mathrm{~mm})$, could have reached around $80 \mu \mathrm{m} \mathrm{d}^{-1}$, if these settlers arrived at the rope collector during the first day of the collector situation. A similar situation occurred in November when the mean tem- perature was $14^{\circ} \mathrm{C}$. In this sense the growth occurring while the mussels were on the collector affects the clear separation between the presence of primary and secondary settlers, but the occurrence of greater length classes $(>2.860 \mathrm{~mm}$ ) confirms the presence of secondary settlers. The scarcity of the length classes $>2.860 \mathrm{~mm}$ on the rope collector suggests that the majority of young post-larvae mussels able to drift occur under this shell length (Sidgurdson et al. 1976, Blok \& Tan Maas 1977). This migration explains the light increase of the length classes $>0.5 \mathrm{~mm}$ detected in November, and the observations of Andreu (1958, $1965,1968)$ about the 2 settlement seasons on rocky shores.

The presence of primary settlers $(<0.500 \mathrm{~mm})$ on the adult beds detected in the present study indicates a direct settlement from the plankton without a previous phase of growth on another substrate. The number of primary settlers $(<0.500 \mathrm{~mm})$ was lower on the adult beds than on the filamentous rope collector. This difference could be explained by the preferential settlement of primary settlers $(<0.500 \mathrm{~mm})$ on filamentous substrates not previously colonized, such as a filamentous rope collector, and also by the mortality of recently settled larvae on the adult beds.

The settlement pattern found in the Ría de Vigo could be explained by the possible genotypic differences between mussel species and the differential mortality as suggested by McGrath et al. (1988). In addition, the difference between settlement patterns could also be a response to the ecological and environmental conditions that occurred on the Galician rocky shores.

Acknowledgements. The authors thank Dr Peter Dare for critically reading the manuscript. J. C.-M. was supported by a grant of the Consejo Nacional de Ciencia y Tecnología (CONACYT) from México and by the Consejo Superior de Investigación Científica (CSIC) from Spain.

\section{LITERATURE CITED}

Aguirre, M. P. (1979). Biología del mejillón (M. edulis) de cultivo de la Ría de Vigo. Boln Inst. esp. Oceanogr. 5(3): $107-160$

Andreu, B. (1958). Sobre el cultivo del mejillón en Galicia: biología, crecimiento y producción. Industrias pesq., Vigo 745-746: $44-47$

Andreu, B. (1965). Biología y parasitología del mejilión Gallego. Ciencias. 30: 17-18

Andreu, B. (1968). Pesquería y cultivo de ostras y mejillones en España. Publicaciones Tecnicas de la Junta de Estudios de Pesca 7:303-320

Andreu, B. (1976). El cultivo del mejillón en europa II. Aspectos biológicos y ecológicos; enemigos y parásitos. Anais Acad. bras. Ciênc. 47-suplemento: 23-35

Bayne, B. L. (1964). Primary and secondary settlement in Mytilus edulis L. (Mollusca). J. Anim. Ecol. 33: 513-523 
Bayne. B. L. (1965). Growth and the delay of metamorphosis of the larvae of Mytilus edulis (L.). Ophelia 2: 1-47

Blok, J. W., Tan Maas, M. (1977). Function of byssus threads in young post-larval Mytilus. Nature 267: 558

Dare, P. J. (1976). Settlement, growth, and production of the mussel, Mytilus edulis L., in Morecambe Bay, England. Fish. Invest. (Ser. 2) 28 (1)

Dare, P. J., Edwards, D. B., Davies, G. (1983). Experimental collection and handling of spat mussels (Mytilus edulis L.) on ropes for intertidal cultivation. Fish. Res. Tech. Rep. Minist. Agric. Fish. Fd, Directorate Fish. Res., Lowestoft 74: $1-23$

Figueras, A. J. (1989). Mussel culture in Spain and France World Aquaculture 20(4): 8-17

King, P. A., McGrath, D., Gosling, E. M. (1989). Reproduction and settlement of Mytilus edulis on an exposed rocky shore in Galway Bay, West coast of Ireland. J. mar. biol. Ass. U.K. 69: 355-365

McGrath, D., King, P. A., Gosling, E. M. (1988). Evidence for direct settlement of Mytilus edulis larvae on adult mussel beds. Mar. Ecol. Prog. Ser. 47: 103-106

Mariño, J., Pérez, A., Román, G. (1982). El cultivo del mejillón (Mytilus edulis L.) en la Ría de Arosa. Boln Inst. esp. Oceanogr. 7 (2): $297-308$

This note was submitted to the editor
Pérez Camacho, A., González, R., Fuentes, J. (1991). Mussel culture in Galicia (N.W. Spain). Aquaculture 94: $263-278$

Pérez, C., Román, G. (1979). Estudio del mejillón y de su epifauna en los cultivos flotantes de la Ría de Arosa. II. Crecimiento, mortalidad y producción del mejillón. Boln Inst. esp. Oceanogr. 5(1): 21-41

Rees, C. B. (1954). Continuous plankton records: the distribution of lamellibranch larvae in the North Sea, 1950-51 Bull. mar. Ecol. 4: 21-46

Seed, R. (1969). The ecology of Mytilus edulis L. (Lamellibranchiata) on exposed rocky shores. I. Breeding and settlement. Oecologia 3: 277-316

Seed, R. (1976). Ecology. In: Bayne, B. L. (ed.) Marine mussels: their ecology and physiology. Cambridge University Press, Cambridge, p. 13-65

Sigurdsson, J. B., Titman, C. W., Davies, P. A. (1976). The dispersal of young post-larval bivalve mollusc by byssus threads. Nature 262: 386-387

Tan, W. H. (1975). The effects of exposure and crawling behavior on the survival of recently settled green mussels (Mytilus viridis L.). Aquaculture 6: 357-368

Widdows, J. (1991). Physiological ecology of mussel larvae. Aquaculture 94: 147-163

Manuscript first received: June 12, 1992

Revised version accepted: December 8, 1992 